
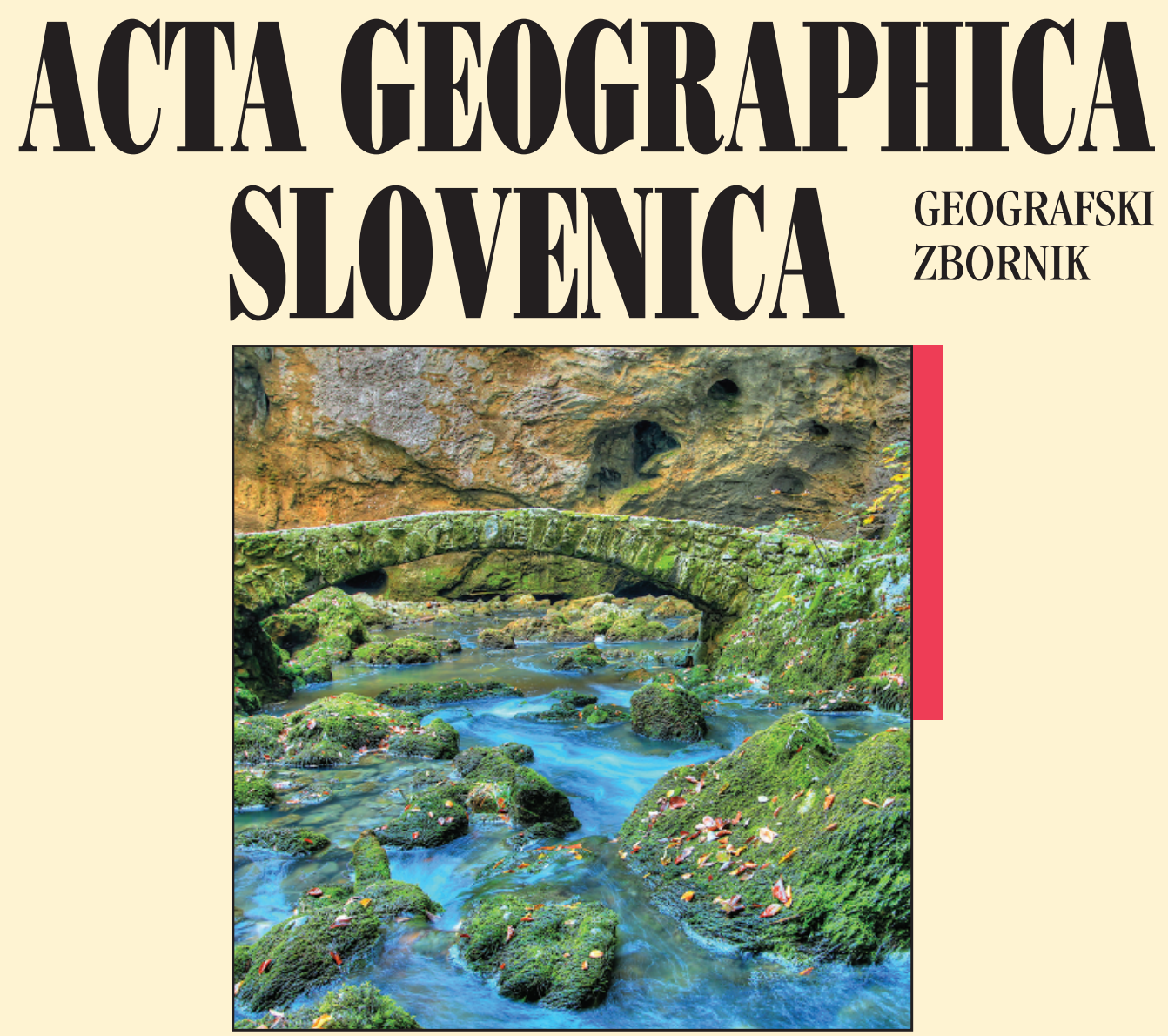


\section{ACTA GEOGRAPHICA SLOVENICA GEOGRAFSKI ZBORNIK \\ 59-1 • 2019}

\section{Contents}

Maja KOCJANČIČ, Tomislav POPIT, Timotej VERBOVŠEK

Gravitational sliding of the carbonate megablocks in the Vipava Valley, SW Slovenia

Małgorzata KIJOWSKA-STRUGAŁA, Anna BUCAŁA-HRABIA

Flood types in a mountain catchment: the Ochotnica River, Poland

Irena MOCANU, Bianca MITRICĂ, Mihaela PERSU

Socio-economic impact of photovoltaic park: The Giurgiu county rural area, Romania

Andrej GOSAR

The size of the area affected by earthquake induced rockfalls: Comparison of the 1998 Krn Mountains (NW Slovenia) earthquake $\left(M_{w} 5.6\right)$ with worldwide data

Matej GABROVEC, Peter KUMER

Land-use changes in Slovenia from the Franciscean Cadaster until today

Mojca FOŠKI

Using the parcel shape index to determine arable land division types

Mateja FERK, Matej LIPAR, Andrej ŠMUC, Russell N. DRYSDALE, Jian ZHAO

Chronology of heterogeneous deposits in the side entrance of Postojna Cave, Slovenia

\section{Special issue - Green creative environments}

Jani KOZINA, Saša POLJAK ISTENIČ, Blaž KOMAC

Green creative environments: Contribution to sustainable urban

and regional development

Saša POLJAK ISTENIČ

Participatory urbanism: creative interventions for sustainable development

Jani KOZINA, Nick CLIFTON

City-region or urban-rural framework: what matters more in understanding

the residential location of the creative class?

Matjaž URŠIČ, Kazushi TAMANO

The importance of green amenities for small creative actors in Tokyo:

Comparing natural and sociocultural spatial attraction characteristics

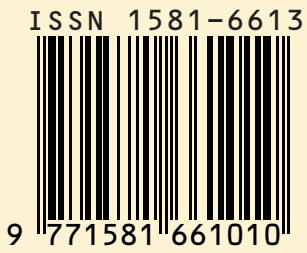




\section{ACTA GEOGRAPHICA SLOVENICA}

$59-1$

2019

ISSN: 1581-6613

COBISS: 124775936

UDC/UDK: 91

(C) 2019, ZRC SAZU, Geografski inštitut Antona Melika

International editorial board/mednarodni uredniški odbor: David Bole (Slovenia), Michael Bründl (Switzerland), Rok Ciglič (Slovenia), Matej Gabrovec (Slovenia), Matjaž Geršič (Slovenia), Peter Jordan (Austria), Drago Kladnik (Slovenia), Blaž Komac (Slovenia), Andrej Kranjc (Slovenia), Dénes Lóczy (Hungary), Simon McCharty (United Kingdom), Slobodan Marković (Serbia), Janez Nared (Slovenia), Drago Perko (Slovenia), Marjan Ravbar (Slovenia), Nika Razpotnik Visković (Slovenia), Aleš Smrekar (Slovenia), Annett Steinführer (Germany), Mimi Urbanc (Slovenia), Matija Zorn (Slovenia)

Editor-in-Chief/glavni urednik: Blaž Komac; blaz@zrc-sazu.si

Executive editor/odgovorni urednik: Drago Perko; drago@zrc-sazu.si

Chief editor for physical geography/glavni urednik za fizično geografijo: Matija Zorn; matija.zorn@zrc-sazu.si Chief editor for human geography/glavna urednica za humano geografijo: Mimi Urbanc; mimi@zrc-sazu.si

Chief editor for regional geography/glavni urednik za regionalno geografijo: Drago Kladnik; drago.kladnik@zrc-sazu.si

Chief editor for spatial planning/glavni urednik za regionalno planiranje: Janez Nared; janez.nared@zrc-sazu.si

Chief editor for rural geography/glavna urednica za geografijo podeželja: Nika Razpotnik Visković; nika.razpotnik@zrc-sazu.si Chief editor for urban geography/glavni urednik za urbano geografijo: David Bole; david.bole@zrc-sazu.si

Chief editor for geographic information systems/glavni urednik za geografske informacijske sisteme: Rok Ciglič; rok.ciglic@zrc-sazu.si

Chief editor for environmental protection/glavni urednik za varstvo okolja: Aleš Smrekar; ales.smrekar@zrc-sazu.si

Editorial assistant/uredniški pomočnik: Matjaž Geršič; matjaz.gersic@zrc-sazu.si

Issued by/izdajatelj: Geografski inštitut Antona Melika ZRC SAZU

Published by/založnik: Založba ZRC

Co-published by/sozaložnik: Slovenska akademija znanosti in umetnosti

Address/Naslov: Geografski inštitut Antona Melika ZRC SAZU, Gosposka ulica 13, SI - 1000 Ljubljana, Slovenija

The papers are available on-line/prispevki so dostopni na medmrežju: http://ags.zrc-sazu.si (ISSN: 1581-8314)

Ordering/naročanje: Založba ZRC, Novi trg 2, p. p. 306, SI - 1001 Ljubljana, Slovenija; zalozba@zrc-sazu.si

Annual subscription/letna naročnina: $20 €$ for individuals/za posameznike, $28 €$ for institutions/za ustanove.

Single issue/cena posamezne številke: $12,50 €$ for individuals/za posameznike, $16 €$ for institutions/za ustanove.

Cartography/kartografija: Geografski inštitut Antona Melika ZRC SAZU

Translations/prevodi: DEKS, d. o. o.

DTP/prelom: SYNCOMP, d. o. o.

Printed by/tiskarna: Tiskarna Present, d. o. o.

Print run/naklada: 350 copies/izvodov

The journal is subsidized by the Slovenian Research Agency and is issued in the framework of the Geography of Slovenia core research programme (P6-0101)/revija izhaja s podporo Javne agencije za raziskovalno dejavnost Republike Slovenije in nastaja v okviru raziskovalnega programa Geografija Slovenije (P6-0101).

The journal is indexed also in/revija je vključena tudi v: SCIE - Science Citation Index Expanded, Scopus, JCR - Journal Citation Report/Science Edition, ERIH PLUS, GEOBASE Journals, Current geographical publications, EBSCOhost, Geoscience e-Journals, Georef, FRANCIS, SJR (SCImago Journal \& Country Rank), OCLC WorldCat, Google scholar, and CrossRef

Oblikovanje/Design by: Matjaž Vipotnik.

Front cover photography: Stone bridge over the Rak River on the outskirts of the Rakov Škocjan polje, which is otherwise known for its beautiful natural bridges (photograph: Matej Lipar).

Fotografija na naslovnici: Kamniti most čez reko Rak na obrobju kraškega polja Rakov Škocjan, ki je sicer bolj znano po čudovitih naravnih mostovih (fotografija: Matej Lipar). 


\section{SOCIO-ECONOMIC IMPACT OF PHOTOVOLTAIC PARK: THE GIURGIU COUNTY RURAL AREA, ROMANIA}

Irena Mocanu, Bianca Mitrică, Mihaela Persu

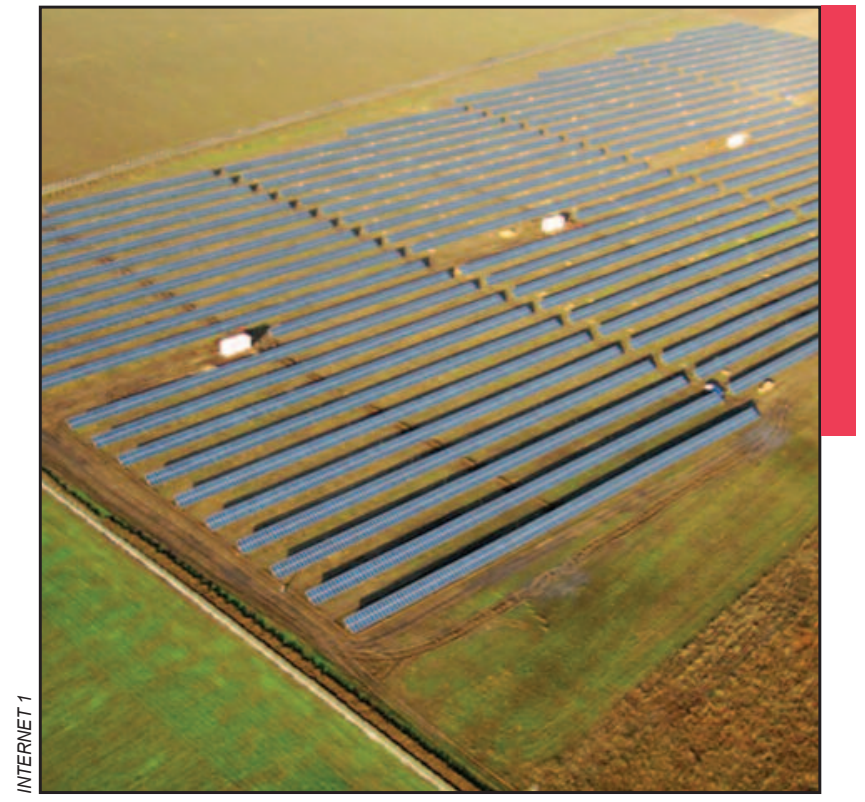

Photovoltaic parks at Stăneşti. 
DOI: https://doi.org/10.3986/AGS.4261

UDC: $911.373: 621.311 .243(498)$

COBISS: 1.01

\title{
Socio-economic impact of photovoltaic park: The Giurgiu County rural area, Romania
}

\begin{abstract}
The paper aims to analyse the socio-economic territorial impact of photovoltaic parks in the rural area of Giurgiu County. The analysis valorises two types of data: the statistical information on the local socio-economic features provided by the National Institute of Statistics and the Giurgiu County Statistics Office, and the specific information about the photovoltaic parks revealed by the interviews applied to the local authorities during field investigation. The case-studies discussed in this paper reflect the socio-economic effects of building and operating the six photovoltaic parks as in the three rural local administrative units - LAU2: Izvoarele, Stăneşti and Malu. This study emphasizes four types of the socio-economic effects of investment in a photovoltaic project on: local rural economy, land use changes, local investments, budget and local labour market.
\end{abstract}

KEY WORDS: geography, solar park, land use, regional development, rural space, Romania

\section{Socialnoekonomski vpliv fotovoltaičnega parka: podeželsko območje Giurgiu v Romuniji}

POVZETEK: V članku avtorice analizirajo socialnoekonomski teritorialni vpliv fotovoltaičnih parkov na podeželskem območju okrožja Giurgiu. Pri analizi so ocenjevale dve vrsti podatkov: statistične podatke o lokalnih socialnoekonomskih značilnostih, ki so jih pridobile na nacionalnem statističnem uradu in statističnem uradu okrožja Giurgiu, ter podatke o fotovoltaičnih parkih, ki so jih med terensko raziskavo pridobile v intervjujih z lokalnimi oblastmi. Predstavljene študije primera izražajo socialnoekonomske vplive gradnje in upravljanja šestih fotovoltaičnih parkov v treh lokalnih upravnih enotah (LUE2): Izvoarele, Stanešti in Malu. Izsledki raziskave so razkrili štiri različne vrste socialnoekonomskih vplivov naložb v fotovoltaične projekte, in sicer vplive na lokalno podeželsko gospodarstvo, spremembe v rabi tal, lokalne naložbe, proračun ter lokalni trg dela.

KLJUČNE BESEDE: geografija, solarni park, raba tal, regionalni razvoj, podeželje, Romunija

Irena Mocanu, Bianca Mitrică, Mihaela Persu

The Romanian Academy, Institute of Geography, Human Geography Department mocanitai@yahoo.com, biancadumitrescu78@yahoo.com,persu_mihaela@yahoo.com

The paper was submitted for publication on $18^{\text {th }}$ August 2015.

Uredništvo je prejelo prispevek 18. avgusta 2015. 


\section{Introduction}

The low-carbon energy transition, a long-term structural change in energy system (Hauff et al. 2014), represents a geographical process (Bridge et al. 2013) which implies the reconfiguration of current patterns and scales of economic and social activity (Smil 2003). Geography offers the concepts which allow us to assess the territorial impacts of energy transition, such as the location, the territoriality, the unequal development, and the scale/level concept (Bridge 2011). The territorial impact of renewable energy, including photovoltaic energy, is one of the many topics emerging from the new geography of energy (Zimmerer 2011) being linked with other concepts such as energy landscape (Nadai and Van der Horst 2010; Pasqualetti 2012), and brightfield (Kunc, Frantál and Klusáček 2011; Kunc et al. 2014). Photovoltaic (PV) parks are »largescale photovoltaic systems designed to supply merchant power to the electricity grid «(Wolfe 2012, 994).

Romania is an ideal location for the installation of the PV systems (Oprea 2008; Pavlíček 2012; Paulescu et al. 2013), the most common being photovoltaic parks and solar thermal systems. Production of renewable energy affects the environment and involves the use of land resources (Sliz-Szkliniarz 2013); also, the development of any type of energy project generates direct and indirect effects on the demand of goods and services as well as employment generation (Caldes, Santamaria and Sáez 2009).

Recent worldwide investigations on the socio-economic impacts of solar park implantation refer to: - social impacts of photovoltaic parks on rural development (Mezei 2008; Pelin et al. 2014; Frantál et al. 2014); - expansion of residential photovoltaic systems (Fekete, Klaić and Majdandžić 2012) and - public acceptance of renewable energies (Zoellner, Schweizer-Ries and Wemheuer 2008).

Kontogianni, Tourkolias and Skourtos (2013) and Gaigalis et al. (2014) bring into question the massive deployment of renewable energy sources from the perspective of the local economy and the local communities. Sliz-Szkliniarz (2013) focused the scientific interest on the risks linked to the use of an intensified renewable energy source use, which should be adequately taken into consideration in any planning of rural areas. The concept of multi-functionality of the rural space relies on the recognition that agriculture, in addition to producing food, also produces non-market goods and services, shapes the environment, affects social and cultural systems, biodiversity conservation and contributes to economic growth (Van Huylenbroek and Durand 2003, cv. Wilson 2010; Van Huylenbroek et al. 2007, cv: Knific and Bojnec 2015; Salvioni 2008). Recent investigation into green jobs shows that this type of employment means fewer jobs (Lyman 2016). The fact that photovoltaic systems require little labour participation is discussed by Pelin et al. (2014).

The issue of territorial impact of photovoltaic parks implanted in Romanian rural areas represents subject of only a few scientific works. Bănică and Istrate (2014) conclude that the jobs are less commun at manufacturing phase of the facilities and more in construction, operating and maintenance phases. Mocanu et al. (2015) hilight loss of farmland as a negative effects of solar park setting up in rural space in terms of land use changes. Pavlíček (2012) analysed markets of some European contries and concluded that the Romanian slow market development is caused by weak education on the photovoltaic technology and by slow bureaucracy in the subsidies system from the EU.

Given this picture, this study concentrates on specific research question: Do photovoltaic parks setting up contribute to the socio-economic development in certain Romanian rural areas? This study attempts to enlarge the current body of literature by analysing at micro-scale the socio-economic impacts of photovoltaic parks setting up, specifically in three rural local administrative units (LAU2): Izvoarele, Malu and Stăneşti (Giurgiu County). In order to estimate such impacts in Romanian rural space, four types of socioeconomic impacts were considered: the rural economic profile before and after the implantation of photovoltaic parks, land-use and land-cover changes, the effects of investments in the photovoltaic industry on the local budget, the real new job opportunities.

\subsection{Study area}

Giurgiu County is located in the Romanian Plain, also known as the Lower Danube Plain (Bălteanu et al. 2006) (Figure 1). 

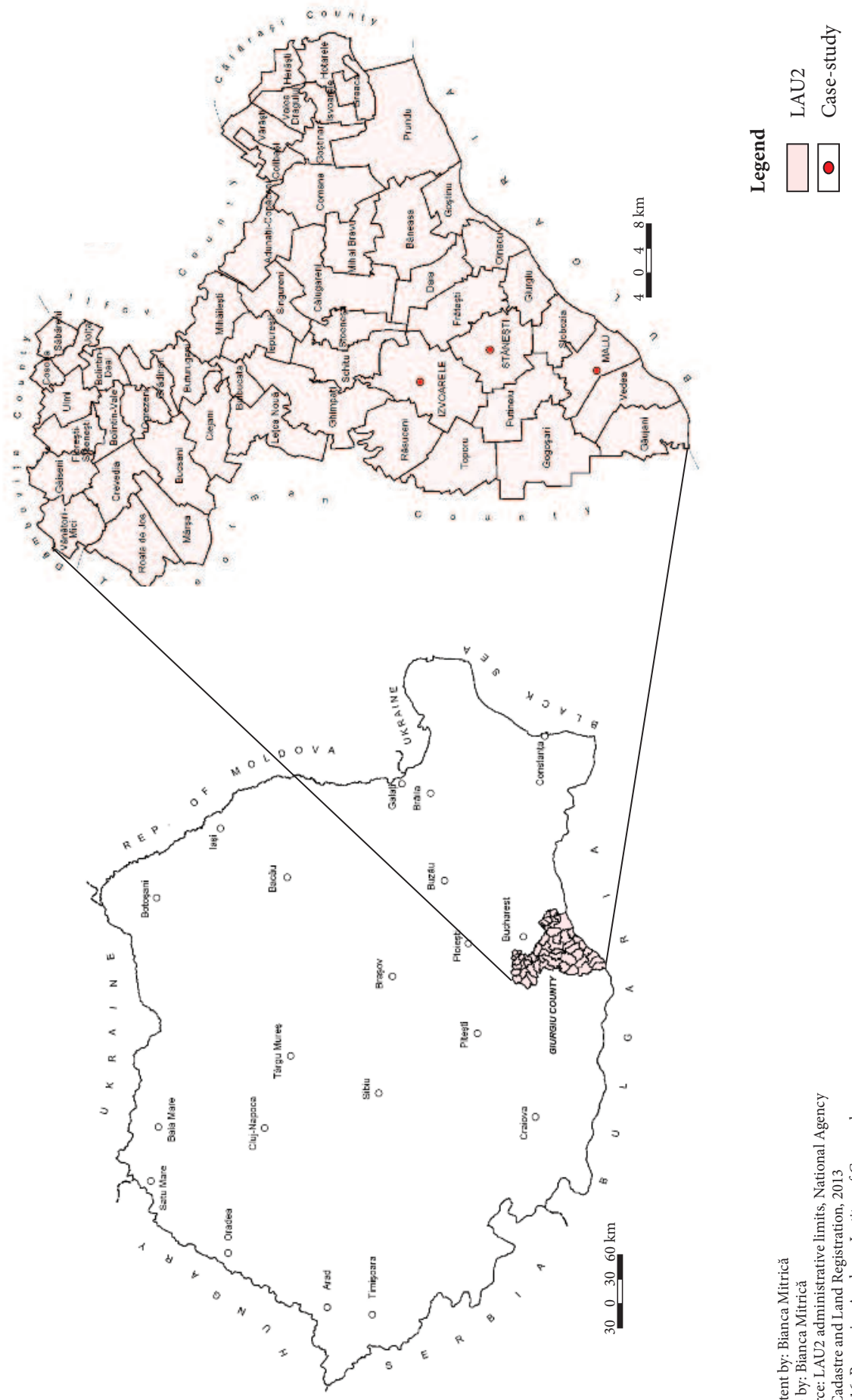
The Giurgiu County includes 3 towns: Giurgiu City (county-seat, an urban pole with regional development potential), Bolintin Vale and Mihăilești, two urban poles with local influence (Giurgiu County Council 2014). Within the Giurgiu County administrative bonds one finds 51 rural LAU2 with 167 villages (Giurgiu County Statistics Office 2012) with low and very low socio-economic development levels (Mocanu et al. 2015). Over the past decade (2002-2012) the county's population fell by 16,437 inhabitants $(-6 \%)$ because of high population ageing, the ageing process increasing the economic dependency rate and inactivity rate values (Kerbler 2015). Iordan (1973; 1998), Gherasim (2003), Ianoş (1999), Săgeată (2004) and Ianoş et al. (2012) show that, in terms of administrative characteristics, the case-studies reported herein are rural areas, although functionally they are located in the peri-urban area of Giurgiu Municipality, inside the Bucharest Metropolitan Area. In turn, this territory is characterised by the alternating countryside with a new emerging urban landscape founded in the former villages surrounding Bucharest City (Mihai, Nistor and Simion 2015).

\section{Key driving factors}

Key driving factors of the photovoltaic energy industry in Romania and in Giurgiu County are:

- High annual average sunshine duration - the Giurgiu County receives over 2,100-2,200 hours of annual average sunshine duration (Oprea 2008). The most important solar regions in Romania are the Black Sea Coast, Dobrogea and the South of the Romanian Plain, with global horizontal irradiation of $1,400 \mathrm{kWh} / \mathrm{m}^{2}$ (Paulescu et al. 2013).

- The EU commitments represent the main background for the photovoltaic energy industry to develop in Romania. In this respect the Giurgiu County Council elaborated two important strategic documents: The 2008-2013 Sustainable Development Strategy and The 2010-2020 Action Plan for Sustainable Energy (Giurgiu County Council 2014).

- The national legislation on renewable energy production (Legea ... 2008) establishing the system that promotes energy from renewable sources, was modified many times. Despite continuous legislative changes, the Romanian renewable energy sector had attracted investments of 3 billion Euro until 2013 (Câmpeanu and Pencea 2014). Beginning with 2014, the legislation intended to reduce the number of green certificates accredited to photovoltaic energy producers, the investors not being eligible to the support scheme if the photovoltaic park is located on cultivable agricultural land (Emergency Government Ordinance 2013). In Giurgiu County (Băneasa municipality), this legal provision was one of the main reasons for the first case of insolvency of photovoltaic industry producers.

- The economic-financial crisis made it difficult for the renewable energy industry to implement the EU provisions, because the generous subsidiaries earmarked to the photovoltaic industry were reduced, as a more stringent budgetary discipline was being imposed (Ghani-Eneland and Chawla 2009). The trade conflicts between China and the EU multiplied the negative impact of the financial-economic crisis and the photovoltaic projects became unprofitable (Zhao et al. 2011; Berger et al. 2012).

These driving forces act in a very complex way, distinctively different at local, national, EU and nonEU levels (Figure 2).

\section{Methods}

To achieve the aims of this study both qualitative and quantitative methods were used (e.g. field investigation, official public statistical documents analysis and interviews (Chelcea 2006; Şandor 2011). The multi-functionality of economy, the issues related to land use and land cover changes and the effects of initial investment in photovoltaic parks on the local budgets were accomplished by using the following indicators: number of photovoltaic energy producers, percentage of farmland covered with photovoltaic parks per total agricultural surface, obtained by an unobtrusive research method, studying official public documents and statistical documents (Babbie 1998; Marshall and Gretchen 2016). The sources of these 

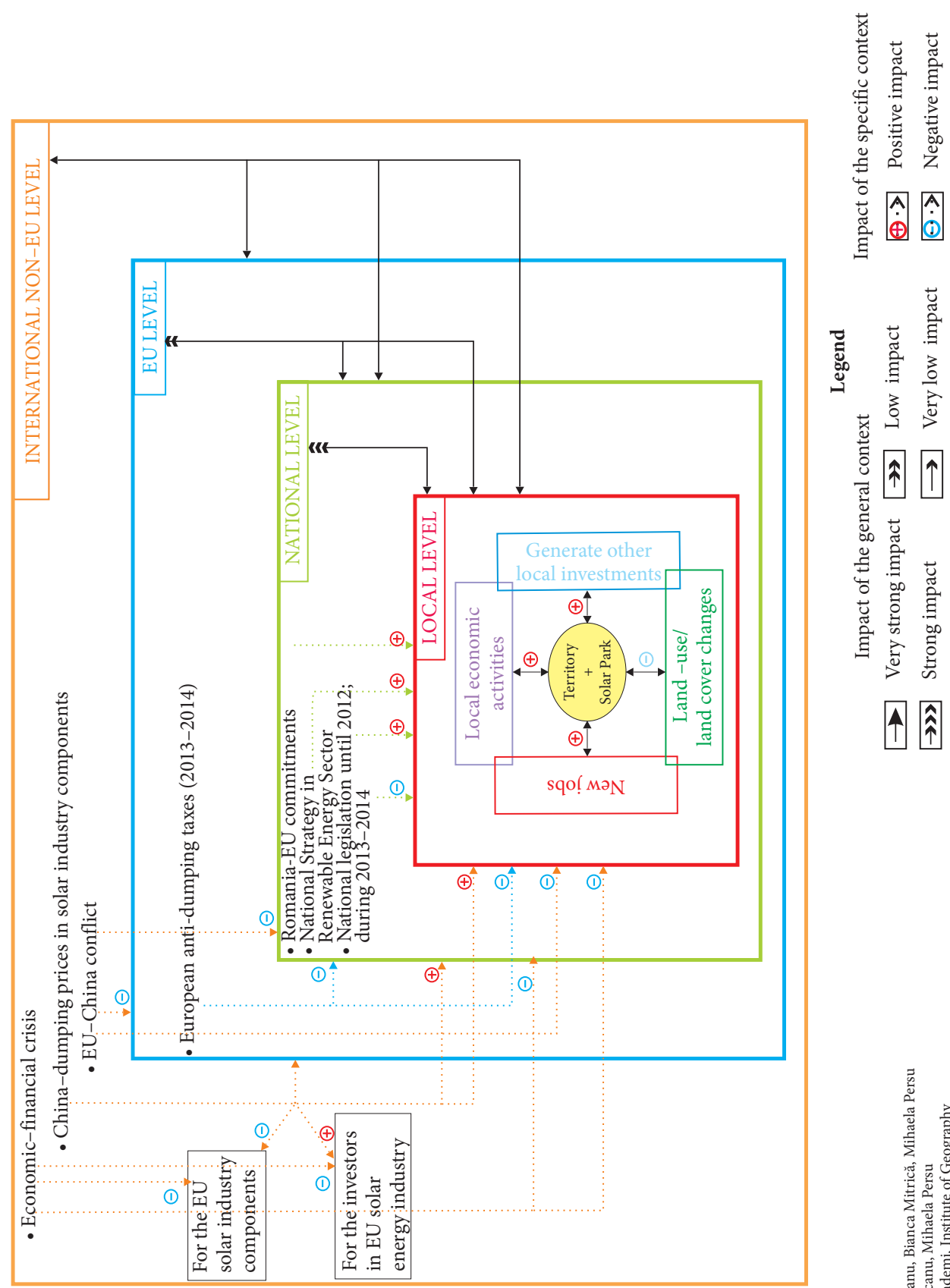

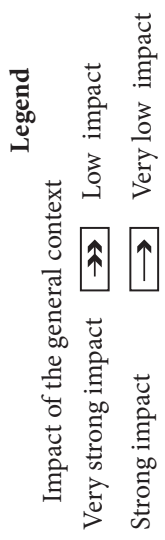
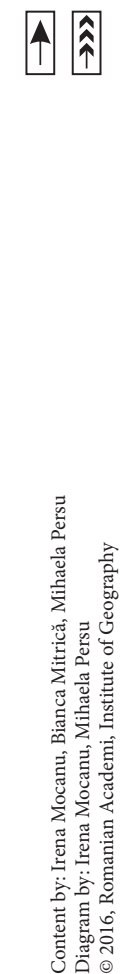
official documents were county and local institutions (Giurgiu County Statistics Office, Giurgiu County Environment Protection Agency, and mayoralties) and national institutions, such as National Institute of Statistics and the National Regulatory Authority for Energy. Also, it was used the Intelligent decision support system for the low voltage grid with distributed power generation from renewable energy resources - InDeSen Project database (Intelligent decision ... 2012).

The official and statistical data were completed with the results of field investigation in the rural settlements of Stănești, Malu and Izvoarele. The interviews were conducted with a total of 30 persons from the three mayoralties during summer 2014. The interviews focused on four issues: land-use and land-cover changes, new jobs, consequences for the local budget (types of taxes) and the community's perception.

\section{Results}

Field investigation has shown the main socio-economic effects of photovoltaic park implantation in a rural area, namely:

- new investments in local economy;

- loss of farmland;

- growth of local budgets;

- new job opportunities.

\subsection{New investments in local economy}

In Giurgiu County, since 2012 new investments in the photovoltaic energy industry have diversified the county's economic profile and have increased the number of companies involved in this field (National Regulatory ... 2014). According to the data provided by National Regulatory Authority for Energy (National Regulatory ... 2014) and the InDeSen Project database (Intelligent decision ... 2012), there are 25 photovoltaic energy producers in Giurgiu County which are operating in 19 rural LAU2 and in Giurgiu Municipality.

The largest photovoltaic parks were setting up in Bucşani, Colibaşi, Izvoarele and Bulbucata rural LAU2. In 2012, the Altius Photovoltaic Company (Bomax Group) began producing photovoltaic panels in Giurgiu Free Zone area, following an investment of 8 million Euros. It is the only manufacturer of photovoltaic panels in Romania. The Company doubled its production capacity to 220,000-230,000 panels/year in 2014 (Altius ... 2016) (Figure 3).

Table 1: The main characteristics of the six photovoltaic parks at lzvoarele, Malu and Stăneşii (Giurgiu County Agency ... 2014).

\begin{tabular}{|c|c|c|c|c|c|}
\hline Investor & Location & Station of connection & Installed power (MW) & Distribution company & Surface (ha) \\
\hline $\begin{array}{l}\text { S.C. BORRA ENERGY } \\
\text { PLANT SRL }\end{array}$ & Izvoarele & Ghizdaru 110/20 kV & 30 & Enel Distributie Muntenia & 72 \\
\hline $\begin{array}{l}\text { S.C. LG GREEN SOURCE } \\
\text { ENERGY BETE SRL }\end{array}$ & Izvoarele & Ghizdaru-Videle 110kV & 20 & Enel Distributie Muntenia & 48 \\
\hline $\begin{array}{l}\text { S.C. LG GREEN SOURCE } \\
\text { ENERGY GAMMA SRL }\end{array}$ & Izvoarele & Ghizdaru-Videle 110 kV & 50 & Enel Distributie Muntenia & 120 \\
\hline $\begin{array}{l}\text { S.C. ECO TRADING } \\
\text { ENERGY SRL }\end{array}$ & Malu & Pietrişu 110/20 kV & 4 & Enel Distributie Muntenia & 9.6 \\
\hline $\begin{array}{l}\text { S.C. LONG BRIDGE } \\
\text { MILENIUM SRL }\end{array}$ & Stăneşti & Ghizdaru 110/20 kV & 7.5 & Transelectrica & 18 \\
\hline $\begin{array}{l}\text { S.C. MONTANA } \\
\text { ENERGY ROM SRL }\end{array}$ & Stăneşti & Ghizdaru 110/20 kV & 5.5 & Enel Distributie Muntenia & 13.2 \\
\hline
\end{tabular}




\subsection{Loss of farmland}

In the Giurgiu County, agricultural land is the main land-use category (75-90\% of total land fund).

In terms of land use and land cover, the photovoltaic parks studied lay on very valuable arable land (Bălteanu et al. 2006), the three photovoltaic parks at Izvoarele occupy 240 ha of farmland with almost 470,000 solar panels. Compared with these large photovoltaic parks, the two parks at Stăneşti cover with photovoltaic

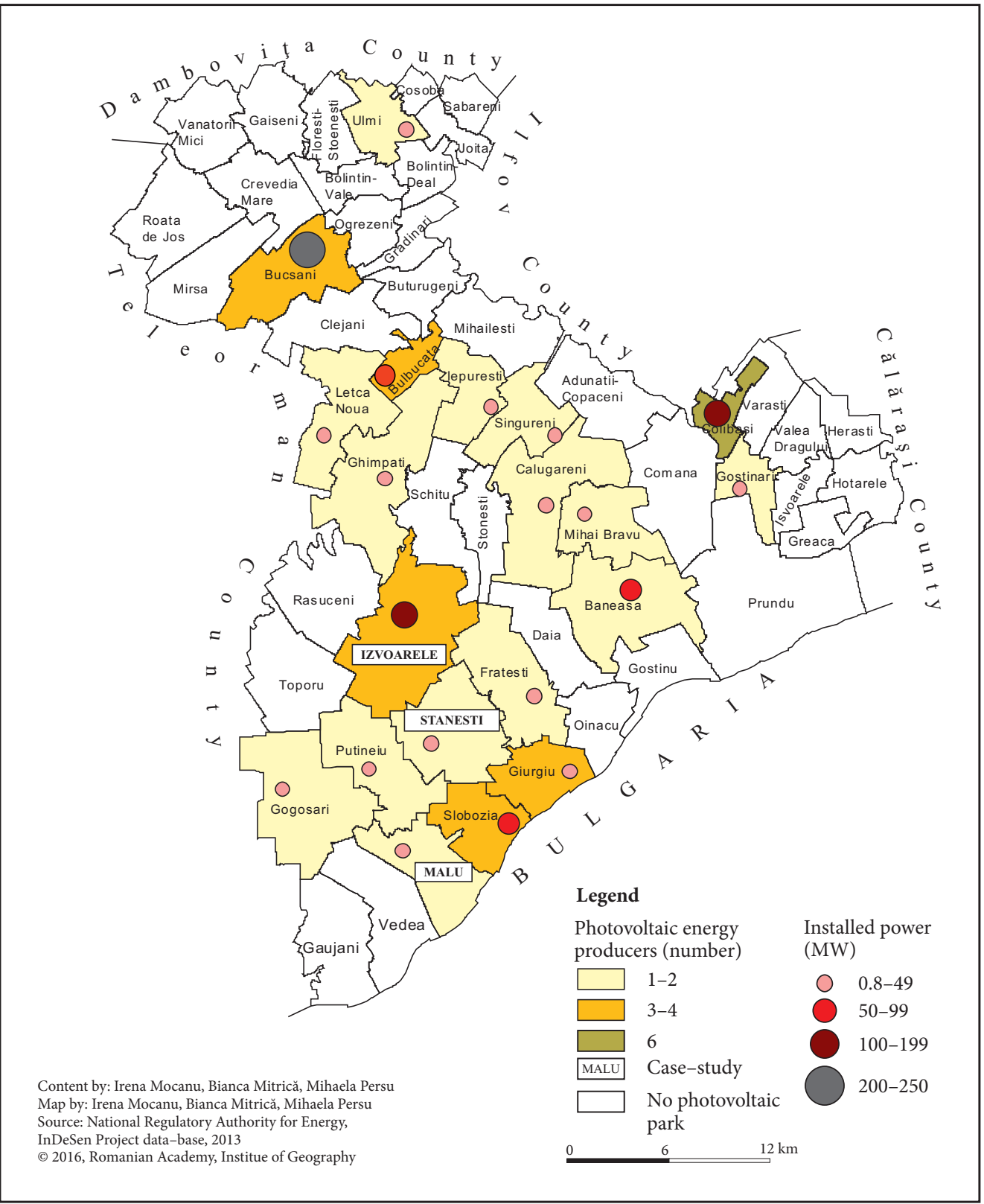

Figure 3: Photovoltaic energy producers in Giurgiu County. 
panels only 30 ha farmland; the photovoltaic park at Malu is built on 9.6 ha of non-agricultural land (19,000 solar panels) (Mocanu, Mitrică and Persu 2015). Our field investigation revealed that farmland areas used for the construction of photovoltaic parks were bought from local farmers (Izvoarele) at prices of 2,000€/ha, and $1,300 € /$ ha (Stăneşti), or conceded for $500 € /$ ha/year (Izvoarele).

Loss of farmland can be described by the percentage of farmland covered with photovoltaic parks per total agricultural surface, the highest losses being registered at Colibaşi (13.08\%). In our case-study, photovoltaic parks occupy small farmland at Stănești (0.47\%) and Izvoarele (2.16\%), while the photovoltaic park at Malu extends on non-farming land. As revealed by the field investigation, in Izvoarele and Stănești, the main land cover category changed by the construction of photovoltaic parks is represented by cultivated areas regularly ploughed and generally under a rotation system (Mocanu, Mitrică and Persu 2015).

\subsection{Growth of local budgets}

Field investigations have shown positive impact of initial photovoltaic parks investments on the local budgets. Interviewing the local authorities from Izvoarele, Stăneşti and Malu we found that the taxes perceived by the mayoralties target the land concession for the setting up of photovoltaic parks, the land sale to investors for setting up solar projects, the building licenses, tax on land, tax on special buildings and a special tax on the installed operation power of each solar project (Figure 4). This type of revenue had a positive impact only if consistently paid annually during the lifetime of a photovoltaic park.

\subsection{New job opportunities - a disputable socio-economic impact}

Investment in a photovoltaic project stimulates new temporary and permanent jobs, directly connected with the building and operation of a solar park and indirectly with other economic activities produced by the initial investment (Figure 5).

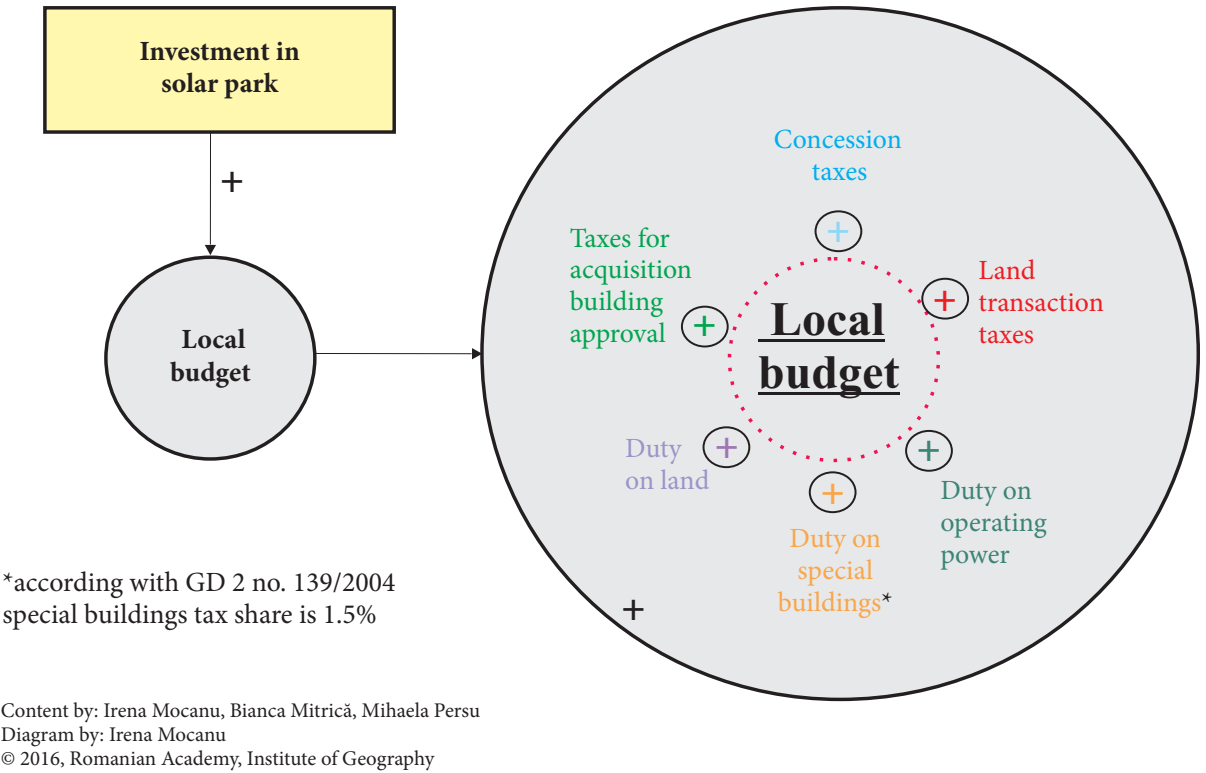

Figure 4: Local investments in solar/photovoltaic parks and the surplus to local budgets. 


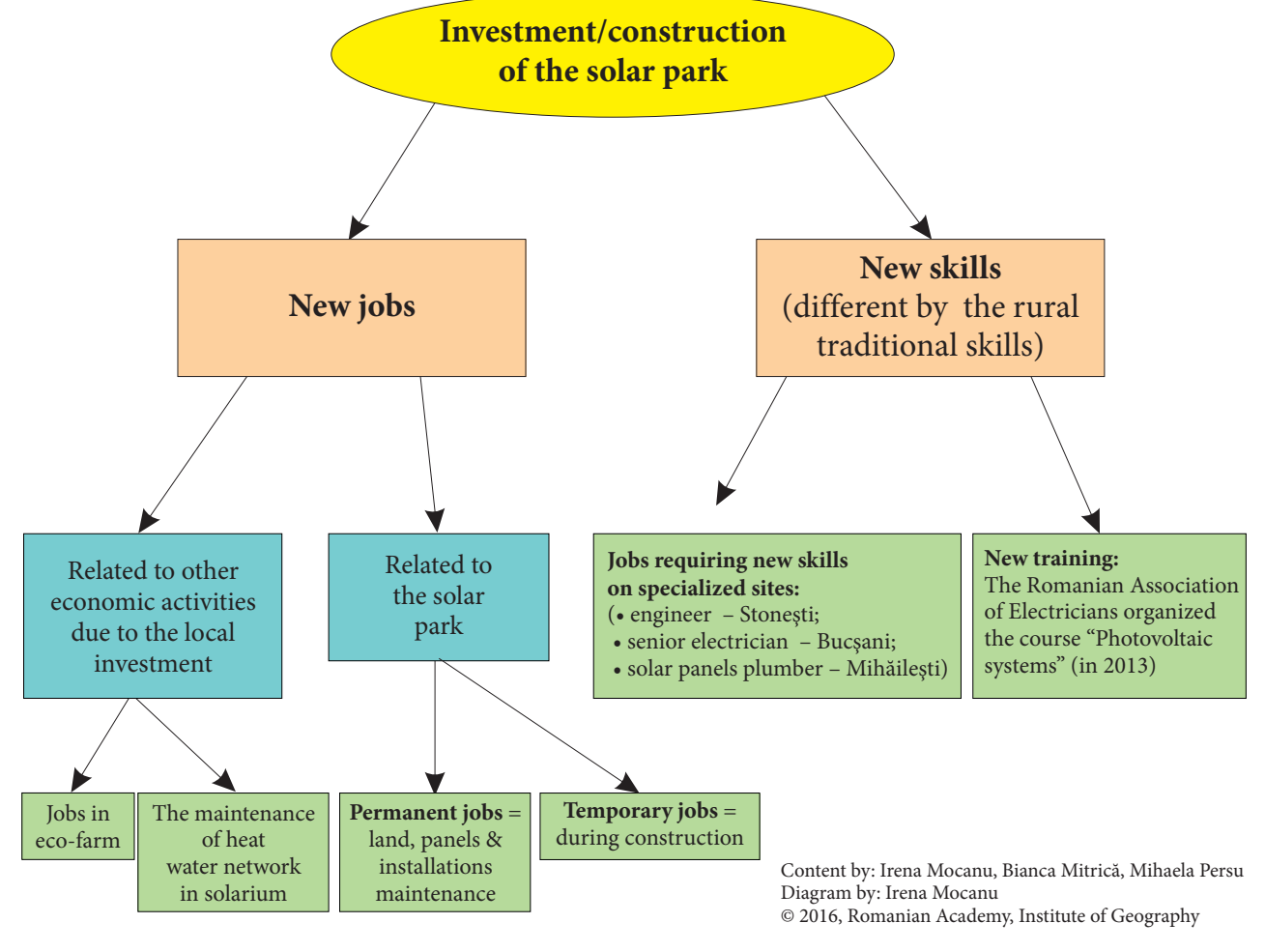

Figure 5: Local investments in photovoltaic parks and new job opportunities.

Field investigations revealed that most new jobs had only a temporary character (during the construction of solar parks), most lower- and medium-skill jobs being occupied by local community members. Thus, for the construction of photovoltaic parks at Izvoarele they employed 50 workers for a period of 12-18 months (depending on the spatial expansion of the park), the building of the Malu photovoltaic park provided jobs for 20 workers over an eight-month interval.

Permanent jobs are scheduled for the maintenance of park grounds (mowing the lawn and up-keeping the road), of photovoltaic panels and the entire specific infrastructure, as well as guards for park protection. At local level, the impact on labour employment is insignificant (2.6\% workers employed for the construction of photovoltaic parks out a total of 1,903 employed in Izvoarele), more people getting jobs (usually unskilled labour) when the site is arranged for mounting the photovoltaic panels and the infrastructure is developed. Only a few guards are employed when the photovoltaic park is operating. The firms entrusted the administration of photovoltaic parks at Izvoarele and Malu are the clients of the Renovatio Assest Management firm in Bucharest, therefore the impact on local employment is nil.

\section{Disscussion}

Both, the authorities and the population were content with the construction of the photovoltaic parks which brought benefits to the local budget and provided jobs for the locals.

The big photovoltaic projects in Giurgiu County had disputable positive impact on rural development. A short-time positive impact is visible only in the case of low- and medium-skilled workers, and also a positive effect is marked only when, and if, taxes and duties are collected. 
At the local level, positive impact on the economy of photovoltaic park implantation is strongly underlined by the local authorities, and the locals' general opinion on solar park is a very good one. Local economy has a multi-functional character only from two viewpoints: firstly, photovoltaic energy actors have joined the economic agents in agriculture and secondly, some farmland has been given other uses, than agricultural. This last aspect of multi-functionality is not necessarily a positive one.

The surplus to local budgets is used to finance several investment projects, e.g. updating some communal roads, equipping and modernising the school and finalising the network of water supply to the households of Radu Vodă Village (Izvoarele). According to Malu Mayoralty, the photovoltaic park provides for the energy consumption of the school, the House of Culture and for public lighting.

Among negative effects of solar project setting up in the rural area (of which are mentioned by Cameron et al. 2012 the temperature and rainfall distribution changes and the damage of biodiversity and soil), we would recall the loss of farmland. This issue was mentioned as a negative effect of solar parks setting up by Hernandez, Ho and Field (2014) and Hernandez et al. (2015). The photovoltaic parks in Izvoarele and Stăneşti cover almost 271 ha farmland, but this negative effect was not mentioned by the local authorities simply because this impact was not being perceived.

According to the officials of the National Regulatory Authority for Energy, the lack of co-ordination between renewable energy deployment and the national grid (due to oversized photovoltaic projects) is quite a problem. However, the local authorities interviewed by us did not mention the surplus of renewable energy resources registered by the rural areas in which solar parks are places.

The photovoltaic parks studied are not functionally integrated into the local communities (according to OECD 2012), because their scale did not reflect local opportunities and the parks are not conceived to serve local demand; moreover do not reflect the local socio-economic and are not managed by the local networks either.

Field investigations revealed that the local communities are not aware of the negative implications of photovoltaic parks for the environment and their unintended climatic consequences, so that the fastgoing development of photovoltaic projects takes advantage of people's ignorance, the of investors's short-term goal being to profit from the legal facilities provided by an investment in the renewable energy industry.

\section{Conclusion}

Despite the dynamics of renewable industry and technology, we noticed that building a photovoltaic park has both negative and positive effects in a rural area, being influenced (even conditioned) by the local context. Field investigations have shown that taxes have a positive impact on the local budgets provided they are paid annually during the lifetime of a photovoltaic park. Regarding the new job opportunities, the positive impact is disputable because most new jobs are temporary and only lower-and-medium skill jobs are occupied by local community members. In terms of land use and land cover, the photovoltaic parks studied are located on very valuable arable land. Loss of farm-land is very much present in the three case-studies discussed in this paper, obviously a negative effect of solar project implantations in the rural area.

ACKNOWLEDGMENTS: The research for this paper was conducted in the framework of research plan of the Institute of Geography of the the Romanian Academ (»The Geographic Study of the Romanian Danube Valley« and »National Geographical Atlas«). The authors contributed equally to the paper.

\section{References}

Altius Photovoltaic Company. Internet: http://www.altiusfotovoltaic.ro (15. 6.2016).

Babbie, E. R. 1998: The practice of social research. Orange.

Bălteanu, D., Badea, L., Buza, M., Niculescu, G., Popescu, C., Dumitraşcu, M. 2006: Romania. Space, society, environment. Bucharest.

Bănică, A., Istrate, M. 2014: Renewable energy emergence - opportunities for a resilient workforce in Romania. Scientific Annals of »Alexandru Ioan Cuza« University of Iaşi - Geography series 60-1. DOI: https://doi.org/ 10.15551/scigeo.v60i1.324 
Berger, A., Fischer, D., Lema, R., Schmitz, H., Urban, F. 2012: China-Europe relations in climate change mitigation: A conceptual framework. Journal of Current Chinese Affairs 42-1. Internet: https://journals.sub.unihamburg.de/giga/.../ (15.3.2016).

Bridge, G. 2011: Resource geographies 1. Making carbon economies, old and new. Progress in Human Geography 35-6. DOI: https://doi.org/10.1177/0309132510385524

Bridge, G., Bouzarovski, S., Bradshaw, M., Eyre, N. 2013: Geographies of energy transition: Space, place and the low-carbon economy. Energy Policy 53. DOI: https://doi.org/10.1016/j.enpol.2012.10.066

Caldes, N., Santamaria, M., Sáez, R. 2009: Economic impact of solar thermal electricity deployment in Spain. Energy Policy 37-5. DOI: https://doi.org/10.1016/j.enpol.2008.12.022

Cameron, D., Cohen, B., Morrison, S. 2012: An approach to enhance the conservation-compatibility of solar energy development. PloS one 7-6. DOI: https://doi.org/10.1371/journal.pone.0038437

Câmpeanu, V., Pencea, S. 2014: Renewable energy sources in Romania: from a "paradise " of investors to a possible abandon or to another boom? The impact of a new paradigm in Romanian renewable sources policy. Procedia Economics and Finance 8. DOI: https://doi.org/10.1016/S2212-5671(14)00072-0

Chelcea, S. 2006: Metodologia cercetării sociologice. Metode cantitative și calitative. București.

Emergency Government Ordinance 2013. Internet: https://goo.gl/Snhzx2 (24. 5. 2015).

Fekete, K., Klaić, Z., Majdandžić, L. 2012: Expansion of the residential photovoltaic systems and its harmonic impact on the distribution grid. Renewable energy 43. DOI: https://doi.org/10.1016/j.renene.2011.11.026

Frantál, B., Pasqualetti, M. J., Van der Horst, D. 2014: New trends and challenges for energy geographies: introduction to the special issue. Moravian Geographical Reports 2-22. DOI: https://doi.org/10.2478/ mgr-2014-0006

Gaigalis, V., Markevicius, A., Katinas, V., Skema, R. 2014: Analysis of the renewable energy promotion in Lithuania in compliance with the European Union strategy and policy. Renewable and Sustainable Energy Reviews 35. DOI: https://doi.org/10.1016/j.rser.2014.04.013

Ghani-Eneland, M., Chawla, A. 2009: Low carbon jobs for Europe. Current opportunities and future prospects. Internet: http://www.wwf.se/source.php/1251673/Low\%20carbon\%20jobs\%20for\%20Europe2009.pdf (24.9.2015).

Gherasim, V. 2003: Studiu privind necesitatea organizării Zonei metropolitane Bucureşti. București.

Giurgiu County Agency for Environment Protection 2014: Mayoralties of Izvoarele, Malu and Stăneşti.

Giurgiu County Statistics Office 2012: Geography and statistics.

Giurgiu County Council 2014: Socio-economic development strategy of Giurgiu County 2014-2020.

Hauff, J., Bode, A., Neumann, D., Haslauer, F. 2014: Global energy transitions. A comparative analysis of key countries and implications for the international energy debate. Berlin.

Hernandez, R., Hoffacker, M., Field, C. 2014: Land-Use Efficiency of Big Solar. Environmental Science \& Technology 48-2. DOI: https://doi.org/10.1021/es4043726

Hernandez, R., Hoffacker, M., Murphy-Mariscal, M., Wu, G., Allen, M. 2015: Solar energy development impacts on land cover change and protected areas. Procedeeings of the National Academy of Science of the USA 112-44. DOI: https://doi.org/10.1073/pnas.1517656112

Ianoş, I. 1999: Analysis of principles, strategic objectives and specific policies of public services in order to achieve regional spatial plan - Bucharest Metropolitan Area. Bucharest.

Ianoş, I., Peptenatu, D., Drăghici, C., Pintilii, R. D. 2012: Management elements of the emergent metropolitan areas in a transition country. Romania, as case study. Journal of Urban and Regional Analysis 4-2.

Intelligent decision support system for the low voltage grid with distributed power generation from renewable energy resources (InDeSen Project) 2012. Internet: http://indesen.ats.com.ro/baza_date/fotovoltaic.php (12.6.2016).

Internet 1: http://www.egnatia-rom.ro/portfolio-item/parc-solar-stanesti-55-mw/ (12.6.2015).

Iordan, I. 1973: Zona periurbană Bucureşti. Bucureşti.

Iordan, I. 1998: Les categories taxonomiques: zone suburbaine, zone périurbaine, zone métropolitaine. 4th Romanian-Polish Geographical International Seminars - Socio-economic changes in the suburban areas of large cities in Romania and Poland. Bucharest.

Kerbler, B. 2015: Population aging in Slovenia: A spatial perspective. Acta geographica Slovenica 55-2. DOI: https://doi.org/10.3986/AGS.1885

Knific, K., Bojnec, Š. 2015: Structural changes in land use of agricultural holdings in hilly rural areas. Acta geographica Slovenica 55-1. DOI: https://doi.org/10.3986/AGS.736 
Kontogianni, A., Tourkolias, C., Skourtos, M. 2013: Renewables portfolio, individual preferences and social values towards RES technologies. Energy Policy 55. DOI: https://doi.org/10.1016/j.enpol.2012.12.033

Kunc, J., Frantál, B., Klusáček, P. 2011: Brownfields as places for renewable sources location? 14th International Colloquium on Regional Sciences. Boretice.

Kunc, J., Martinát, S., Tonev, P., Frantál, B. 2014: Destiny of urban brownfields: Spatialpatterns and perceived consequences of post-socialistic deindustrialization. Transylvanian Review of Administrative Sciences 41-E.

Legea pentru stabilirea sistemului de promovare a producerii energiei din surse regenerabile de energie 220/2008. Monitorul Oficial I-577, 13.8.2010.

Lymann, R. 2016: Green jobs - rhetoric or reality? A brief review of the evidence. Internet: https://www.friendsofscience.org/assets/documents/Green-Jobs-Rhetoric_Lyman.pdf (24.7.2016).

Marshall, C., Gretchen, B. R. 2016: Designing qualitative research. Los Angeles.

Mezei, C. 2008: The role of Hungarian local government in local economic development. Discussion papers 63.

Mihai, B., Nistor, C., Simion, G. 2015: Post-socialist urban growth of Bucharest, Romania - a change detection analysis on Landsat imagery (1984-2010). Acta geographica Slovenica 55-2. DOI: https://doi.org/ 10.3986/AGS.709

Mocanu, I., Mitrică, B., Persu, M. 2015: Consequences of setting up photovoltaic parks-related land use/land cover changes in Giurgiu County rural area (Romania). Carpathian Journal of Earth and Environmental Sciences 10-4.

Mocanu, I., Mitrică, B., Vîrdol, A., Şerban, P. 2015: Territorial patterns of socio-economic development in the Romanian Danube Valley. Forum geografic 14-2. DOI: https:/doi.org/10.5775/fg.2067-4635.2015.168.d

Nadaï, A., van der Horst, D. 2010: Landscapes of Energies. Landscape Research 35-2. DOI: https://oi.org/ $10.1080 / 01426390903557543$

National Regulatory Authority for Energy, 2013: List of economic operators and power plants accredited to apply the system of green certificates, December 2013. Internet: http://www.anre.ro/en/electric-energy/ public-info (24.7.2016).

OECD green growth studies 2012. Linking renewable energy to rural development. DOI: https://doi.org/ 10.1787/9789264180444-en

Oprea, C. 2008: Radiația solară, Clima României. Bucureşti.

Pasqualetti, M. 2012: Reading the changing energy landscape. Sustainable Energy landscapes: designing, planning, and development. DOI: https://doi.org/10.1201/b13037-4

Paulescu, M., Paulescu, E., Gavrilă P., Bădescu, V. 2013: Solar radiation measurements. Weather modeling and forecasting of PV system operation. DOI: https://doi.org/10.1007/978-1-4471-4649-0_2

Pavlíček, M. 2012: Overview of the situation on photovoltaic market in selected eastern European states after world crisis in 2011. Equilibrium 7-3. DOI: https://doi.org/10.12775/EQUIL.2012.023

Pelin, D., Šljivac, D., Topić, D., Varjú, V. 2014: Regional impacts of different photovoltaic systems. Pécs.

Săgeată, R. 2004: Zonele metropolitane în România. Revista Română de Geografie Politică 6, 1-2.

Salvioni, C. 2008: Diversification, multifunctionality and pluriactivity in Italian FADN. Internet: http://www.fao.org/fileadmin/templates/ess/pages/rural/wye_city_group/2009/Paper_1_4_Aguglia_Diver sification_and_Multifunctionality_in_Italy_and_the_Netherlands.doc (11.6.2014).

Sliz-Szkliniarz, B. 2013: Assessment of the renewable energy-mix and land use trade-off at a regional level: A case study for the Kujawsko-Pomorskie Voivodship. Land Use Policy 35. DOI: https://doi.org/ 10.1016/j.landusepol.2013.05.018

Smil, V. 2003: Energy at the crossroads: Global perspectives and uncertainties. Cambridge.

Şandor, D. S. 2011: Metode şi tehnici de cercetare folosite în ştiințele sociale. Cluj-Napoca. Internet: http://www.apubb.ro/wp-content/uploads/2011/02/Suport-MTCS-Ro.pdf (15. 11.2016).

Van Huylenbroeck, G., Vandermeulen, V., Mettepenningen, E., Verspecht, A. 2007: Multifunctionality of agriculture: A review of definitions, evidence and instruments. Living reviews in landscape research 1-3. DOI: https://doi.org/10.12942/lrlr-2007-3

Wilson, G. 2010: Multifunctional »quality« and rural community resilience. Transactions of the Institute of British Geographers 35-3. DOI: https://doi.org/10.1111/j.1475-5661.2010.00391.x

Wolfe, P. R. 2012: Solar parks and solar farms. Practical handbook of photovoltaics, fundamentals and applications. Oxford. 
Zhao, Z. Y., Zuo, J., Feng, T. T., Zillante, G. 2011: International cooperation on renewable energy development in China - A critical analysis. Renewable Energy 36-3. DOI: https://doi.org/10.1016/j.renene.2010.09.002

Zimmerer, K. 2011: The new geographies of energy. Annals of the Association of American Geographers 101-4. DOI: https://doi.org/10.1080/00045608.2011.575318

Zoellner, J., Schweizer-Ries, P., Wemheuer, C. 2008: Public Acceptance of Renewable Energies: Results from Case Studies in Germany. Energy Policy 36-11. DOI: https://doi.org/10.1016/j.enpol.2008.06.026 